\title{
Breeding of field bean (Vicia faba L.) with early maturity
}

\author{
SIMO HOVINEN
}

\author{
Hankkija Plant Breeding Institute \\ SF-04300 Hyrylä, Finland
}

\begin{abstract}
Breeding work to develop varieties adaptable to Finnish conditions was initiated at the Hankkija Plant Breeding Institute in 1969. The production of field bean seeds was considered a means of substituting for imported protein feed sources. Finland is a very marginal production area; varieties grown in Finland must be adapted to sowing in May and to short summers with long days and cool autumn weather. Local populations maturing early were frequently used in crosses with foreign material. Strains from the ICARDA collection and Soviet varieties included in the crosses considerably increased the genetic basis of the breeding material. Some 214 crosses were made in 1970-87. Two commercial varieties, Hankkijan Mikko and Hankkijan Ukko, were released during the course of the programme. They were about two weeks earlier in maturing than, e.g. the German variety Herz Freya.

Crosses and selections of current interest are aimed at reaching still earlier maturity than that of Mikko and Ukko. Determinate habit with $t i$ gene has been transferred to locally adapted early material in order to attain lines with reduced vegetative growth, uniform ripening and improved lodging resistance. The white-flowered character is combined with earliness and determinate habit in order to obtain a lowered tannin content in seeds.
\end{abstract}

Index words: Vicia faba, field bean, breeding for earliness, determinate habit, adaptability breeding

\section{Introduction}

Cultivation of the field bean, though rare, is one way of producing domestic protein for feed mixes in Finland. At the end of the 1960s, adaptive protein crops were sought to replace the overproduction of cereals by effective protein producers, such as oilseed rape, peas and field beans. The breeding of field beans was started at the Hankkija Plant Breeding Insti- tute's Anttila Experimental Farm because adaptive and uniform varieties were not available. Small-scale cultivation of local strains had been carried on for decades, but the strains were not suitable for combine harvesting, and they were populations with segregating seed colour and size. Local strains provided, however, valuable characteristics of adaptability for basic material in breeding. During the years 1969 - 74, samples of 15 strains were 
collected from eight localities in southeastern Finland (Hovinen and KIVI 1975, KIVI 1979). These strains are available from the Nordic Gene Bank, Sweden.

In comparison with peas, field beans offered superior lodging resistance and protein concentration in seeds. At the end of the 1970 s, the high capacity of symbiotic nitrogen fixation by field beans attracted increasing attention and offered the possibility of intercropping it with cereals. Farmers, especially dairy farmers, have proved the suitability of bean yield for feed mixes on farm scale (SYRJÄLÄ-Qvist 1986), and user experiences of the feed industry have also been positive. The farmer's decision to grow field bean is often motivated by the fact that the field bean is an effective break crop in a cereal monoculture.

During the $1980 \mathrm{~s}$, the availability of gene sources for low tannin content in seeds as well as determinate growth habit have greatly stimulated breeding, which for many years was of low intensity.

\section{Breeding material}

The first step in breeding was to select single plants from local strains to develop uniform breeding lines. The lines were used extensively in crossings with foreign material in order to generate large variability (Fig. 1). Some lines proved to be heavy-yielding, but others were characterized by lower yield combined with extreme earliness. The variety Hankkijan Mikko, released in 1977, belongs to the latter category.

From 1975 to 1978 , selection work was carried out to increase the L-DOPA content in the leaves of breeding lines (von SCHANTZ et al. 1976, 1977). The line Hja 60053 (Koričnevyje/ Hja 70001) was found to possess the highest concentration of this medicine.

A great number of crosses were carried out in 1978 in order to combine earliness and other characteristics of adaptability with the genetic diversity of the ICARDA collection. Disease resistance, in particular, was sought. The white-flowered variety Triple White offered the possibility of combining a lower tannin content with locally adapted material (MAR. QUARDT et al. 1978). Some local strains were still available for use in crosses.

The first result of the crossbreeding programme was the release of the variety Hankkijan Ukko in 1984.

The main object of the crosses made in 1984 to 1987 was to transfer the gene for determinate habit ( $t i$ gene) into the most adaptive, early line material. The gene was obtained from the variety Bruno by M. Frauen Lembke, GFR. In addition, some other Central European varieties were crossed with early maturing, white-flowered lines in order to transfer high-yielding capacity into the material.

At the beginning of the crossbreeding programme, a very simple selection method was applied, where single plant selections were first made in the $F_{4}$ or $F_{5}$ generation from freely pollinated populations. Later on, the need emerged to renew the selection with bagisolated plants in order to obtain uniform lines. Since 1985, there has been a change over to the pedigree method, which enables a more effective selection.

\section{Breeding for earliness}

Neither local strains nor gene bank material seem to offer genetic resources of earliness which would fulfill the final goal of developing a field bean ideotype for Finland. Late maturity seriously limits the value of the field bean as a field crop. Although the variety Ukko belongs to the earliest maturity category, its growing time exceeds the growing times of important field crops almost crucially (Fig. 2). Especially in cool seasons, the growing time of the field bean is even longer than the growing time of the spring rape, which is the latest crop on average. In comparison with varieties of more southern origin, the earliest variety this far, Mikko, has a growing time over two weeks shorter than Sving, Herz Freya or Primus (Table 1). The variety Troy, classified as early in the condi- 


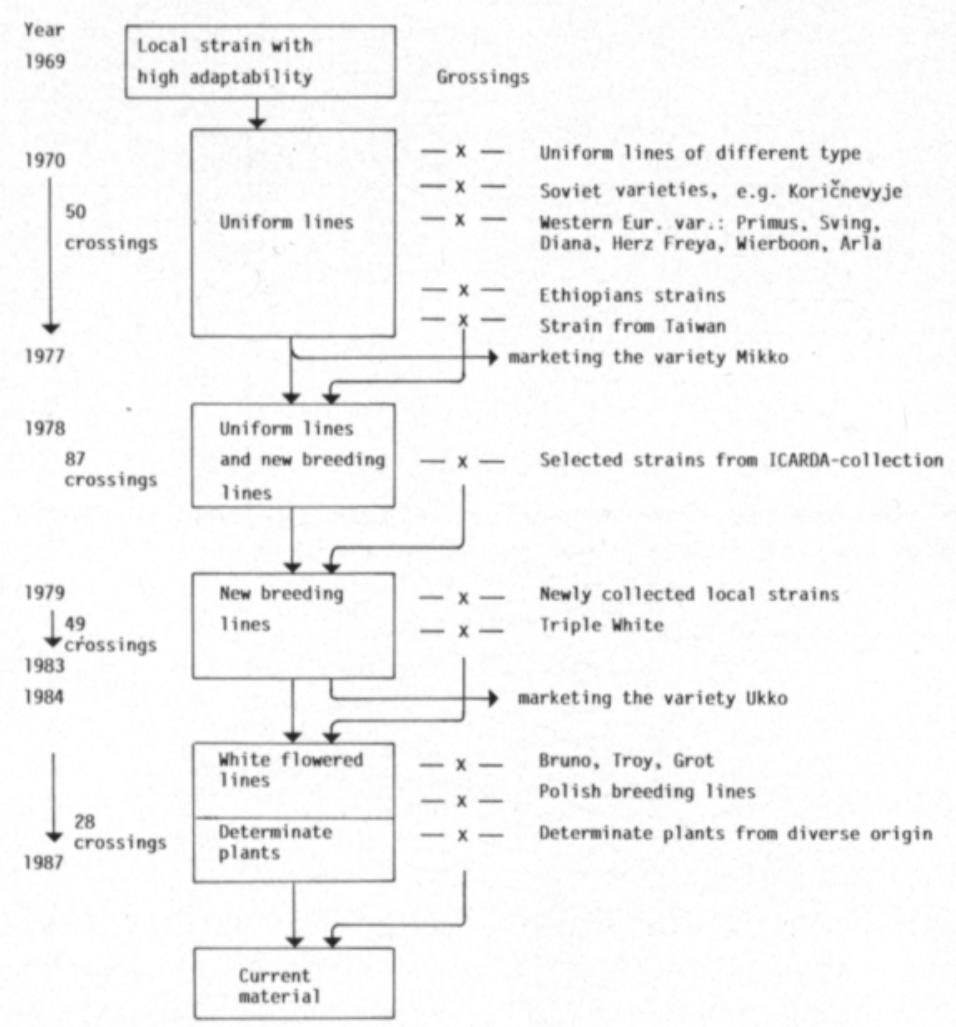

Fig. 1. Breeding scheme for field bean.

tions prevailing in Germany (BOND 1987), in Finland has usually difficulties in reaching maturity.

One cannot expect very rapid progress in breeding for a decisively earlier maturity class, which should have a growing time of about 101-105 days on average. Among the new material (Table 2), the earliest line, Hja 61612, is only two days earlier than Mikko. The season of 1986 was dry, with exceptionally short growing times for the varieties. Due to the high lodging resistance of the field bean as compared to the pea, the acceptable growing time is longer for the former. In Finland, pea varieties should have a growing time of 91-101 days (Hovinen 1988).

In the current selection work, still earlier segregants in the material managed by the pedigree system are frequently sought. Most interesting are the pedigrees from crosses where the earliest selections have been crossed with determinate plants from the first crosses with Bruno. Observations of new determinate pedigrees show that the difference in ripening date between the lowest and the highest podded node is much shorter in determinates than in indeterminates. More experience will be

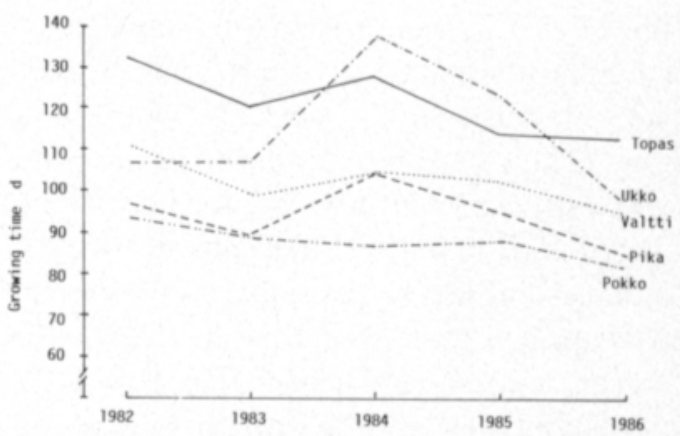

Fig. 2. Growing time of Pokko, 6-rowed spring barley, Pika pea, Valtti spring turnip rape, Ukko field bean and Topas spring rape in the main trials at Anttila in 1982-1986. 
Table 1. Field bean variety Mikko with early maturity as compared to later maturing varieties in Finnish variety trials in $1972-80$.

\begin{tabular}{lccc}
\hline Variety & $\begin{array}{c}\text { Growing time } \\
\mathrm{d}\end{array}$ & $\begin{array}{c}\text { Seed yield } \\
\text { rel. value }\end{array}$ & $\begin{array}{c}\text { Crude } \\
\text { protein- } \%\end{array}$ \\
\hline Mikko & 108 & $2,770 \mathrm{~kg} / \mathrm{ha}=100$ & 30.8 \\
Pirhonen (Finnish) & +7 & 116 & +0.2 \\
Arla (Swedish) & +8 & 104 & +0.6 \\
Sving (Swedish) & +15 & 114 & -2.1 \\
Herz Freya (German) & +17 & 131 & -1.1 \\
Primus (Swedish) & +19 & 126 & -1.0 \\
\hline
\end{tabular}

Table 2. Statistics of some varietal characteristics of the field bean. The main trial at Anttila in 1986 included 54 breeding lines and the standard varieties of Mikko and Ukko.

\begin{tabular}{lccrr}
\hline Characteristic & Mean & Range & Mikko & Ukko \\
\hline Yield kg/ha & 3,030 & $2,280-3,810$ & 2,280 & 2,930 \\
Growing time d & 101 & $95-109$ & 97 & 97 \\
Tsw. g & 308 & $220-372$ & 220 & 299 \\
Crude protein \% & 27.3 & $25.2-29.0$ & 28.0 & 27.5 \\
\hline
\end{tabular}

needed if the determinates show less shattering of early flowers and pods (Bond 1987), which could affect further progress in earliness.

\section{Seed yield}

In Finland, the only possibility is to grow varieties ripening early enough, such as Mikko and Ukko. The penalty reflected in yield, as compared to late varieties, can be as high as $31 \%$ (Table 1). It is interesting, however, to note that though the variety Ukko is only two days later than Mikko, it is $20 \%$ better in yield (Hovinen 1984). This yield difference must hide factors other than the small difference in earliness. Variety trials frequently reveal wide ranges in the yield of new breeding lines (Table 2). It is necessary to consider the yields of every breeding line for many years in comparison to the trial means. If the yield of a breeding line keeps significantly above the trial mean in successive years, its yield capacity can be considered dependable. Late varieties exhibit high yields in warm or normal seasons, but in cool seasons their yields do not ripen and the hectare yield must be considered to be nil. A number of lines exceeded the yield of the variety Ukko in the trial for 1986; many trials in successive years will be needed to see if some lines with acceptable growing time will surpass the yield of this standard variety.

In its main cultivation zone, the variety Ukko produces $60-65 \%$ of the hectare yield of the best cereal varieties (Hovinen 1984). The yielding capacity of Ukko is somewhat lower than the well adapted pea variety Pika (Fig. 3). Oilseed rape varieties cannot compete with the field bean as to yield.

Experience from cool autumns shows that large-seeded varieties have difficulties in ripening. This factor begins to have an effect when the 1,000 seed weight exceeds $300 \mathrm{~g}$. Keeping to small-seededness will prove the progress in yield breeding to be slow (DANTUMA et al. 1983). The highest hectare yield ever produced by Ukko on the Anttila farm is $5,000 \mathrm{~kg} / \mathrm{ha}$. Ukko has a mean 1,000-seed weight of $291 \mathrm{~g}$.

The highest hectare yield produced by Anttila thus far is $6,380 \mathrm{~kg}$. The producer was the line Hja 70001 (a selection from a local population of Nuijamaa), one parent of Ukko. $\mathrm{Hja}$ 70001 had a 1,000 -seed weight of $319 \mathrm{~g}$. Thus small-seeded varieties can reach high yields, but the high yield by this line was combined with lateness. 
The most attractive means of breeding for higher yielding capacity is thus to combine a somewhat larger seed size, $300-400 \mathrm{~g} / 1,000$ seeds (Table 2) with significantly earlier maturity than Ukko. A seed size of $300-400 \mathrm{~g}$ / 1,000 seed is still small enough to be acceptable to farmers, who pay attention to seeding costs.

The yield level of more than six tons reveals that there is a genetic basis for high yields. The varietal characteristics preventing attainment of that level must be ascertained before breeding for ideotype can be successful.

\section{Objectives of adaptation}

In Finland, where the growing seasons are short and the days long, a high-yield variety should be able to get the most from the abundant light available in May and June. Though the current field bean varieties exhibit a more rapid growth rate than field peas during the first weeks after sowing, a still faster growth would undoubtedly be beneficial in increasing the final yield. The relative growth rates of breeding lines are thus observed regularly, and rapidly growing lines favoured.

A recent finding is that the field bean is not well adapted to growing in a dense stand. The currently recommended sowing rate is 70 seeds $/ \mathrm{m}^{2}$. If the conditions of a growing season favour luxuriant growth, the recommended rate has too much of an effect on flower drop, the spread of diseases and lodging. On the other hand, lowering the seeding rate generates too thin a stand if the vegetative growth should be weak. Two solutions to the problem are possible. The sowing rate could be lowered if the variety had a very rapid growth rate and if single plants had the tendency to grow big. A somewhat larger seed size would be needed for developing this variety type. The other solution could be found by developing a determinate plant type with a restricted vegetative growth; such a variety could be sown at a density of about 70 seeds $/ \mathrm{m}^{2}$.

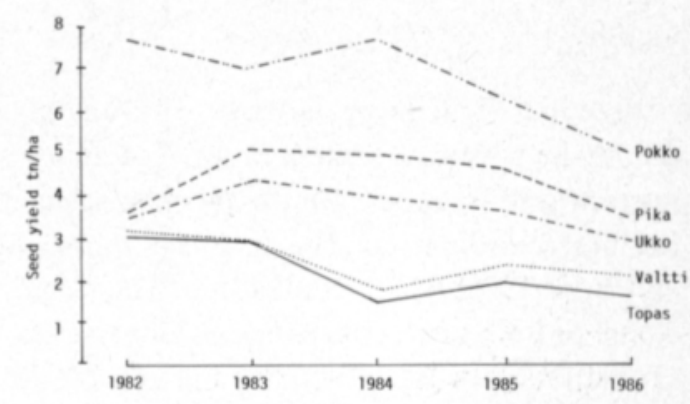

Fig. 3. Seed yields of Pokko, 6-rowed spring barley, Pika pea, Valtti spring turnip rape, Ukko field bean and Topas spring rape in the main trials at Anttila in 1982-1986.

There is no need to spread nitrogen for the field bean (Hovinen and VARIS 1983). During the breeding process, and effective nitrogen fixation of the lines must be guaranteed. Unquestionably good drought resistance is a prerequisite for uninterrupted nitrogen fixation. Susceptibility to disease is another main factor interfering with nitrogen symbiosis. If a variety possesses a moderate resistance against these stress factors, it is likely to be highly effective in nitrogen binding, which in turn is a qualification for high yielding capacity.

Disease stress is mainly caused by Botrytis spp. (Ruokola and Vestberg 1978). Varietal differences are observed frequently, but no breeding line thus far has proved to be properly resistant. Some lines, though infected, obviously are able to tolerate the disease without severe yield losses. The variety Ukko has this characteristic (Hovinen 1985). One can say that the variety is adapted to disease stress. Suitability for mixed cropping is a special kind of varietal adaptation. Growing the field bean in mixed stand with oats is a usual practice in northern cultivation areas. The current varieties are satisfactorily suitable for cultivation in mixed stand, but the question remains how well, for instance, determinate lines will compete with cereals in the stand. In all probability, the field bean variety intended for mixed stands will be of a different ideotype than that meant for pure stand cultivation. 


\section{Quality}

Breeding field bean varieties with an optimally high protein content has played an important role in decision-making when selecting breeding lines for the future (CHAPMAN and Peat 1978, SAyed et al. 1982). The range of the protein content between older varieties (Table 1) and between breeding lines (Table 2) is not wide. The current breeding work, however, does not place high priority on screeing for high protein content. Efforts must be directed towards improving the factors affecting adaptability, which in turn diminishes fluctuations in seed yield. High seed yield is the prerequisite for high protein yield, the amount of which is the measure of protein productivity. All new breeding lines of field bean seem, however, to surpass the current breeding lines of peas as far as protein content is concerned. If all breeding lines with low and medium protein content were discarded, too much variability for selection for high seed yield would be lost.

Part of the existing breeding material is white-flowered, which is usually assumed to mean a low tannin content in seeds. The first white-flowered breeding lines have shown a somewhat inferior yielding capacity when compared to the coloured-flower genotype. White-flowered lines often also seem to exhibit a weak establishment of stand, reflecting difficulties in germination. Obviously, difficult selection work is needed to develop highly adapted white flowered varieties.

\section{References}

Bond, D.A. 1987. Recent Developments in Breeding Field Beans (Vicia faba L.). Plant Breeding 99: 1-26.

Chapman, G.P. \& Peat, W.E. 1978. Procurement of yield in field and broad beans. Outlook on Agric. 9: $267-272$.

Dantuma, G., von Kittutz, E., Frauen, M. \& Bond, D.A. 1983. Yield, Yield Stability and Measurements

\section{Marketed varieties}

Hankkijan Mikko is a selection from a local strain collected from southeast Finland (Hovinen 1982). Mikko is an extremely early, small-seeded (200 g/1,000 seeds) variety with a brown-black seed colour. It has a medium protein content $(31.1 \%)$ and a low yield $(2,410 \mathrm{~kg} / \mathrm{ha})$.

Hankkijan Ukko originates from the cross Koričnevyje/Hja 70001 (HovinEN 1984). Ukko is two days later than Mikko. It has small seeds (292 g/1,000 seeds) with a white seed coat colour. Its protein content is $29.1 \%$, the seed yield being $2.940 \mathrm{~kg} / \mathrm{ha}$.

\section{Future prospects}

The field bean has been considered a minor crop in breeding, and so little resources have been allocated to it. However, the prospects for advancement are encouraging. New gene sources for resistance to Botrytis spp. and Ascochyta fabae are now available (JELLIS et al. 1982, 1984). It should be possible to improve the harvest index (DANTUma et al. 1983), which is low (45 \% at the highest) for the actual varieties of Mikko and Ukko. Several mutants for determinate growth habit have been found to increase variation (SJÖDIN 1971, NaGl 1978, Filippetti 1986). Semi-determinants have also been developed (FrAUEN and BRIMo 1983). Transferred to locally adapted breeding lines, the determinated habit shows evidence of improving many characteristics affecting agronomic suitability. of Morphological and Phenological Characters of Faba Bean (Vicia faba L.) Varieties Grown in a Wide Range of Environments in Western Europe. Z. Pflanzenzüchtg. 90: 85-105.

FII.IPPETTI, A. 1986. Inheritance of Determinate Growth habit Induced in Vicia faba major by Ethyl Methane Sulphonate (EMS). FABIS Newsl. 15: 12-14. 
Frauen, M. \& Brimo, M. 1983. The inheritance of Semideterminate Growth in Vicia faba (L.). Z. Pflanzenzüchtg. 91: 261-263.

Hovinen, S. 1982. Hankkijan Mikko -härkäpapu. Hankk. kasvinjal.l. Tiedote 7: 1-20.

- 1984. Hankkijan Ukko -härkäpapu. Hankk. kasvinjal.1. Tiedote 14: 1-12.

- 1985. Härkäpapu. Hankk. Siemenjulkaisu 1985: 98-101.

-1988 . Breeding of a protein pea ideotype for Finnish conditions. J. Scient. Agric. Soc. Finl. 60: 7-72.

— \& Kıvı, E. 1975. Härkäpapu. Hankk. Siemenjulkaisu 1975: 64-66.

— \& VARIS, E. 1983. Palkoviljat. Biologinen typensidonta peltokasvien viljelyssä. Suomen Akatemian sopimustutkimuksen no. 383 loppuraportti. p. 127-174.

Jeluis, G.J., Bond, D.A. \& OLD, J. 1982. Resistance to chocolate spot (Botrytis fabae) in Icarda accessions of Vicia faba. FABIS Newsl. 4: 53-54.

-, Lockwood, G. \& Aubury, R.G. 1984. Resistance to ascochyta blight (Ascochyta fabae) in a winter-hardy line of faba bean (Vicia faba equina). Fabis Newsl. 10: 27-29.

Kıvı, E. 1979. Züchterische Aspekte der einheimischer Eiweissversorgung im Norden. J. Scient. Agric. Soc. Finl. 51: 1-16.

Marquardt, R.R., Ward, A.T. \& Evans, L.E. 1978.
Comparative properties of tannin-free and tannin-containing cultivars of faba beans (Vicia faba). Can. J. Plant. Sci. 58: 753-760.

NAGL, K. 1978. Breeding value of radio-induced mutants of Vicia faba var. minor. Seed Protein Improvement in Grain Legumes. p. 234-252. Vienna.

Ruokola, A-L. \& Vestberg, M. 1978. Fungus diseases of field bean in Finland during 1975-1977. J. Scient. Agric. Soc. Finl. 50: 455-467.

Sayed, F.E., Nakkoul, H. \& Williams, P. 1982. Distribution of protein content in the world collection of faba bean (Vicia faba L.). Fabis Newsl. 5: 37.

Schantz, M. von, Huhtikangas, A., Hiltunen, R. \& Hovinen, S. 1976. Züchtung von Pferdebohnensorten mit hohem L-DOPA-Gehalt. I. Variabilităt des LDOPA-Gehaltes. Sci. Pharm. 45: 201-212.

-, Huhtikangas, A., Hiltunen, R. \& Hovinen, S. 1977. Züchtung von Pferdebohnensorten mit hohem L-DOPA-Gehalt. II. Vergleichende Untersuchungen der Veränderungen des L-DOPA-Gehaltes im Untersuchungsmaterial während zwei verschiedener Wachstumsperioden. Sci. Pharm. 46: 101-105.

Sıódın, J. 1971. Induced morphological variation in Vicia faba. Hereditas 67: 155-180.

Syrjälä-Qvist, L. 1986. Palkokasvien käyttö rehuna. SITRA. Biologisen typensidonnan ja ravinnetypen hyvăksikăytön projekti, Tietolehtinen 7: 1-7.

\section{SELOSTUS}

\section{Aikaisin tuleentuvan härkäpavun (Vicia faba L.) jalostus}

\section{Simo Hovinen}

\section{Hankkijan kasvinjalostuslaitos 04300 Hyrylä}

Härkăpavun jalostus Hankkijan kasvinjalostuslaitoksella aloitettiin 1969. Jalostustyössä on pyritty kehittämäăn puimurikorjuuseen sopivia, riittävän aikaisin tuleentuvia lajikkeita, joita viljelemällä rehuvalkuaistuontia ulkomailta voidaan văhentää. Lajikkeiden tulee olla sopeutuneita pitkään päivăän, ajoittaiseen kuivuuteen, kasvitautipaineeseen ja pystyä tuleentumaan viileissả syyssäissả.

Kasvuoloihin sopeutuneita, mm. Parikkalan, Savitaipaleen, Lappeenrannan ja Nuijamaan paikalliskantoja on toistuvasti käytetty jalostusaineiston perustana. Niitä on risteytetty ulkomaisten lajikkeiden ja kantojen kanssa, joista on erityisesti mainittava ICARDAn kokoelma Syyriasta ja neuvostoliittolaiset lajikkeet. Vuosina 1970-1987

tehtiin 214 risteytystå.

Jalostustyön kuluessa on laskettu kauppaan 2 lajiketta, Hankkijan Mikko 1977 ja Hankkijan Ukko 1984. Ne ovat riittävăn aikaisia viljeltåvăksi eteläisimmässă osassa Suomea.

Nykyisessä jalostustyössä keskitytaaän kehittämään Mikkoa ja Ukkoa aikaisempia lajikkeita, perustuen todennäköisesti ti-geenin hyväksikäyttöön päätteellisen kasvutavan aikaansaamiseksi. Päätteellinen kasvutapa lieventäisi myös kasvitautien leviämistä ja estäisi lakoontumista. Merkittăvă osa uusista jalostuslinjoista on valkokukkaisia tanniinipitoisuuden alentamiseksi siemenkuoressa. 